\title{
Pension Reforms in Universities: Dilemmas and Countermeasures
}

\author{
Jing Xin \\ Nanyang Institute of Technology \\ Nanyang, Henan 473004, China
}

\begin{abstract}
At present, China's economy has shifted from highspeed growth to a new normal of medium-to-high-speed growth. Although labor mobility is accelerating, population aging is becoming more prominent. Accordingly economic and social structure is constantly adjusting, and social pension insurance system is facing severe challenges. Taking the reform of pension insurance system in colleges and universities as a breakthrough, through comparative analysis, this paper reveals the current situation and problems of the pension insurance system in colleges and universities, expounds the necessity and urgency of the implementation of pension reform in colleges and universities, and combines the actual situations of colleges and universities to reform the pension insurance system in colleges and universities. At last, it also puts forward corresponding countermeasures and suggestions.
\end{abstract}

Keywords-University; Pension reforms; Endowment insurance

\section{INTRODUCTION}

The unit system is the most important organizational form of Chinese urban society in the long period after the founding of the People's Republic of China. The main reason for the rise of the unit system is based on the needs of national governance and political integration. "The social control of the state and the government is mainly achieved through the unit, and the unit's will to implement the national integration and control is mainly based on the overall dependence of the unit members on the unit. The process is implemented" [1]. The uniqueness of the endowment insurance system of government agencies and institutions has been criticized by all walks of life. It is a general trend for the institutions to implement a unified basic old-age insurance system and to eliminate the 'dual-track system'.

At the beginning of the 2015 New Year, Guofa [2015] No. 2 Document "Decision of the State Council on the Reform of the Endowment Insurance System for Staff and Institutions of the Institutions and Institutions" (hereinafter referred to as "Decision") was introduced. This is a landmark document that marks the previous, long-term, difficult and complicated reform of the pension insurance system of institutions, and institutions has already had a clear outline, and it also marks the formal integration of the "dual-track system" of enterprises, institutions and careers that are widely concerned in society.

On the other hand, the greater socio-political significance of the Decision is that it solves the problem of guaranteeing the choice of units and units by means of institutionalization. This issue is also implicit in the enduring pension system to maintain social equity in a lot of controversy. As a pivotal institutional arrangement, the pension insurance system allows the institutional space for the exchange of intellectual resources and economic resources to be extended and can be directly completed without relying on the unit, thus facilitating the implementation and return of the choice of units and units.

\section{THE STATUS QUO OF CHINA'S PENSION INSURANCE SYSTEM}

Endowment insurance is a social insurance system. It is related to medical insurance, maternity insurance, unemployment insurance and other basic areas of the socia security system. The pension insurance system is established to enable workers to reach the statutory retirement age or lose their ability to work due to old age. After the basic life providing the most direct and basic life guarantee, fundamentally protect the legitimate rights and interests of workers and maintain social security and stability [1]

At the beginning of the construction of China's endowment insurance system, we did not establish a unified pension insurance system. Instead, we adopted the idea of "division of urban and rural areas and occupational management", as well as implemented different policies for personnel in different industries. According to the type of population, it can be divided into urban enterprise employees. Pension insurance, endowment insurance for institutions and institutions, and rura pension insurance. With the rapid development of politics and economy, our country's pension insurance system has also undergone a complicated development process, and it highlights the important characteristics of the "dual track system". It is manifested in two aspects: the parallel of urban and rural pensions and the dual-track operation of occupational pensions. In any aspect, it shows the obvious difference in the form and treatment level of the pension insurance system. This difference is mainly due to different ways of co-ordination and payment channels, as well as different treatment standards [2].

With the promulgation of the "Decision", it is required that "the government and institutions will implement the basic oldage insurance system that combines social pooling and individual accounts, and the two will pay according to a certain proportion, and the amount of payment will be directly linked to the pension expenses after retirement. "In this way, the above differences will inevitably be gradually reduced." This 
reform measure is not only related to the personal interests of college faculty and staff, but also related to the development of college education, and more to the construction of a harmonious society, so it plays an important role in the development of the entire social security system [3].

Due to historical reasons, most of China's colleges and universities and their faculty and staff did not participate in social pension insurance. For a long time, college teachers do not need to pay old-age pensions. After retirement, the school will issue different amounts of retirement wages according to the teacher's working age, professional title, honors and contributions. This part of the funds is mainly from the state's funding and the school's own. Revenue. Of course, due to the different levels of colleges and universities, there are certain differences in the pension funds for retired teachers assigned to each school. As China's economy gradually enters the "new normal" of China's rapid development, the pressure on the state's finance is gradually increasing. Coupled with the aging population problem, the traditional "national pension" model no longer adapts to the state and colleges. development of. At the same time, the public has obvious dissatisfaction with the differences in this pension system. Reforming the pension system of colleges and universities has not only become an inevitable requirement for promoting the sustainable development of the social economy, but also a social demand for maintaining social prosperity and stability.

\section{THE NECESSITY OF PENSION REFORM IN PUBLIC INSTITUTIONS}

Reason one: The "dual track system" of old-age security is controversial and heated in the society. At the end of the last century, enterprise employees began to implement the endowment insurance system, and they were at the forefront of the reform of old-age security. The institutions and institutions have been extending the retirement system that is financed by retirement expenses, and the reform of old-age security is relatively slow. Enterprises need individual payment of endowment insurance, but the pension benefits are generally low, and they are not linked to social and economic development in a timely manner. They do not share the results of reform and development in a timely manner; while institutions and institutions do not need to pay endowment insurance, instead they enjoy higher pensions. Gold treatment. Therefore, a situation in which the pension gap between enterprises and retirees is relatively large has formed, which has led to the polarization of the rich and the poor, which has become a factor of social disharmony and instability.

Reason 2: From the perspective of the whole society, because of the different pension systems, the rational flow of talents between enterprises and enterprises is restricted to some extent, and is often plagued by some problems, such as: transfer of pension insurance relationship, length of service review Wait.

Reason 3: As the population ages and the life expectancy of the population increases, the dependency ratio increases, which inevitably increases the pressure on the balance of pensions. The ability to pay for old-age security will also face a huge test. Therefore, it is imperative to establish a unified pension system throughout the country, which is also the inevitable result of historical development.

\section{THE PROBLEMS IN THE REFORM OF THE ENDOWMENT INSURANCE SYSTEM IN COLLEGES AND UNIVERSITIES}

The reform of the pension insurance system in colleges and universities is a process of setting a new foundation, and it is destined to be a long and complicated process. Since the decision of the State Council to promulgate the endowment insurance reform of institutions and institutions on January 3, 2015, the pace of reform of institutions and institutions has been generally slow. College teachers, as a relatively special group, are facing severe challenges and tests.

\section{A. The restraint of traditional ideas hinders the progress of reform}

As China's economy shifts from high-speed to mediumhigh speed, China's current economic and social structure is facing a huge impact. Some old things and old systems that cannot keep pace with the times will inevitably be eliminated by the giants of the times. The reform of the education system, the medical reform, the de-administration of colleges and universities, etc., the emergence of this series of new things is an inevitable outcome of the development of society to a certain period. According to incomplete statistics, the number of organs and business establishments in China has reached more than 30 million. It can be said that this is a huge group. The implementation of the reform of pension insurance for institutions and institutions will break the "iron" that this group has long relied on for survival. "The rice bowl" is difficult to accept for a time. Even the colleges and universities with highskilled elements are greatly constrained in their ideological concepts. At present, many colleges and universities and their faculty and staff have remained at a relatively primitive stage in their understanding of pension reform. The understanding is still vague: on the one hand, they do not want to change the current relatively stable living conditions, and the necessity and urgency of reform are lacking. On the other hand, they do not want to take part of their monthly salary to pay pension insurance, but they believe that the result of the reform will inevitably affect or even lower their post-retirement treatment, and psychologically have a serious negative impact on this reform. Emotions are difficult to accept this reform in terms of ideas [4].

\section{B. Difficulties in docking with enterprise pension insurance}

Due to the existence of the "dual track system", there are great differences in the system between urban and rural enterprises and institutions. Generally speaking, the endowment insurance system implemented by urban and rural enterprises has a dedicated social security institution for overall management, and the agency business unit adopts the current financial system of pay-as-you-go, which fundamentally determines that there will be great problems and difficulties in the docking of the two [4]. Moreover, as far as the current situation is concerned, with the continuous advancement of college education and personnel system reform, the employment methods of colleges and universities have become more and more flexible, and the personnel situation has 
become more and more complicated. Business, personnel, contract, mobile, etc. Etc. These different categories of personnel cannot be generalized in the process of reform, and they must face many complicated problems in the process of connecting with enterprises.

\section{The university itself faces a higher cost of conversion}

At present, colleges and universities generally implement a retirement pension system. The pension of faculty and staff is entirely borne by the state and the university itself. It is a form of pay-as-you-go. After the transfer, this pay-as-you-go system will accumulate with the current fund of the enterprise. The combination of the system produces a new partial accumulation system of social pension [5]. During the transition period of the restructuring, the old employees who have retired before the reform of the node still follow the retirement pension system. In addition to the personal account pension and the basic pension, the retirees who retired after the reform of the node need a corresponding amount of transitional pension to fill the gaps they have accumulated. Because colleges and universities did not pay any pensions before the reform, many faculty and staff members were unable to accumulate enough pension funds after retirement. This part of the blanks need to be covered by the pension insurance system, which directly constitutes the hidden pension insurance. Liabilities. At the same time, according to the provisions of the pension insurance reform, in addition to the $20 \%$ of the total wages, the colleges and universities will pay the pension insurance contributions and part of the occupational annuity payment according to $8 \%$ of the total wages, which in turn increases the cost of colleges and universities. For most colleges and universities, the pressure is very important, which is an important challenge that colleges and universities cannot avoid during the reform process.

\section{Heavy reform tasks}

After the reform of the endowment insurance in colleges and universities, the accounting of pension insurance for retired faculty and staff should be based on individual personnel file materials. Therefore, whether the basic data is accurate and complete will affect the reform process to a large extent. Therefore, we must do a good job in personnel affairs. Collection, screening, and cleaning of archival materials, especially materials related to date of birth, time of work, position (title), and length of service. For colleges with large bases and complex identities, this will be a huge "engineering" that is time consuming and labor intensive. At present, colleges and universities generally exhibit a variety of forms of employment and a complicated salary calculation method, which makes the definition of total wages more difficult, thus affecting the determination of the payment base. In order to promote the smooth progress of the endowment insurance reform in colleges and universities, universities need to cooperate with each other to study and formulate a series of institutional reforms and innovations that are compatible with the old-age insurance system, fundamentally breaking through the long-standing institutional obstacles and reforming the oldage insurance. The smooth implementation of clearing the road will inevitably be a relatively long process.

\section{E. The lack of legal basis for reform}

At present, the state has not yet introduced corresponding laws and regulations for the reform of endowment insurance for government agencies and institutions, and still stays at the level of policy constraints. The binding effect is very limited, resulting in a lack of foundation for system construction. The implementation of various policies is very weak and severely constrained. The pace of reform. This has directly led to the shackles of college pension insurance reform, and the road to reform is even more difficult.

\section{THE COUNTERMEASURES TO PROMOTE THE REFORM OF ENDOWMENT INSURANCE IN COLLEGES AND UNIVERSITIES}

Colleges and universities should put the reform of the pension insurance system at a strategic level, deeply understand the importance, complexity and urgency of the reform of the pension insurance system. Based on the difficulties of the current reform, implement targeted countermeasures to ensure the pension insurance system of colleges and universities. The reform has been implemented and the results have been achieved.

\section{A. Strengthening the publicity of public opinion and establish correct value orientation.}

The reform of endowment insurance in colleges and universities is a difficult process of breaking the old system and establishing a new system. It is bound to be resisted by traditional concepts and various social trends. It is necessary to constantly strengthen public opinion propaganda and establish correct value orientation. First of all, we must grasp the propaganda point of view and use the model of reverse thinking to influence and infect the majority of faculty and staff, so that they can clearly understand that the reform of the pension insurance system is to break the old system and continuously improve the social security system on the basis of safeguarding the interests of the faculty and staff. An active act to promote social equity is not to deprive school retired workers of their right to pension. The implementation of this reform is the inevitable result of the continuous development of society. It is in line with the social needs of the continuous development of higher education and is conducive to the construction of college teachers and the improvement of the quality of education and teaching. Secondly, colleges and universities should continue to innovate propaganda models and make full use of new media such as WeChat, Weibo, and digital campuses to timely and accurately communicate the contents, goals, and processes of reform to the faculty and staff, so that every college faculty member can get out of the misunderstanding. Into the reform, integration into the reform, and thus actively participate in reform. 


\section{B. Improving the reform system for college teachers' endowment insurance and realize a smooth transition between old and new systems}

The reform of the endowment insurance in colleges and universities is to break the old pension insurance system of "double-track operation" and improve the social pension security system. It is necessary to pay attention to the docking and integration between the two tracks, properly handle the interests of all parties in the society and need to maximize the national finance. relieve pressure. In the era of "Internet plus", the reform of the pension insurance system in colleges and universities must make full use of existing information tools and means to actively build big data on human resources in colleges and universities, which strive to make scientific and rational decision-making programs based on data. In addition, as a highland for teaching and educating people, colleges and universities must always adhere to the "people-oriented" concept, take into account the vested interests of all types of personnel, and must adhere to the old and new systems, the overall planning of new and old personnel, and gradual progress, both to consider the old system. The vested interests of the retirees should also consider the pension balance of the "Chinese people", but also solve the problem of "newcomers" pension replenishment, and finally achieve a smooth transition between the old and new systems.

\section{Increasing investment in higher education and reduce the cost of colleges and universities}

As an important national decision-making, the reform of the endowment insurance system of colleges and universities must play the leading role of the government. In the process of reform, in the face of increasing pension insurance costs and supplementary funds for the transition period, all colleges and universities will face huge transformation costs. In order to ensure the smooth progress of the reform of colleges and universities and to relieve the worries of the faculty and staff, the state needs to continuously optimize the economic and social structure, and at the same time, it needs to continuously innovate and develop ideas, thereby promoting economic and social transformation and steady improvement of the social economy. In addition, the state needs to fundamentally increase investment in education, increase the proportion of social insurance funds, and form a linkage mechanism between the central government, local governments, and universities to ensure the maximum amount of funds for college pension reform.

\section{Deepening the reform of the personnel system in colleges and universities and promoting the steady progress of pension insurance reform}

To promote the reform of the endowment insurance system in colleges and universities, colleges and universities need to combine business practice with the new situation of economic and social development, continuously expand ideas, develop and innovate, and actively promote the reform and development of the existing personnel management system. In the process of exploring the reform of pension insurance, colleges and universities can fully learn from the experience of enterprise pension insurance management, break the institutional and institutional obstacles in unit management, and actively explore social security systems suitable for the development of modern universities and meet the needs of the faculty and staff. Achieve seamless integration with the enterprise employee pension insurance system. In accordance with the principle of "streamlining, unification, and efficiency", focusing on large-scale, informatization, and high-performance reforms, we will promote the scientific, standardized, and legalized establishment of management institutions, and establish an organizational structure consistent with the school development needs and regulations. Management system; improve the performance salary system reform, increase competitive performance, explore and establish a diversified salary distribution system, establish a reasonable growth mechanism for wages and salaries of incumbents; establish a new teacher pre-employment system, strictly control the entry, encourage teachers Competition for employment, embodying fairness; for retirees, explore and innovate a variety of compensation methods to ensure that the oldage treatment of institutions and institutions after the merger is not reduced, and achieve a soft landing of pensions.

\section{E. Establishing and improving the institutionalization and legalization of endowment insurance to ensure reforms are law-abiding}

According to the current pension insurance system, the government should unify the laws and regulations on the old-age insurance system, and on the other hand, formulate relevant social security policies and regulations for the actual situation of higher education. It is necessary to encourage university teachers to advance from the establishment of the pension payment base, the definition of the payment period, and even the payment and payment of pensions, and to follow the path of legalization. It is necessary to strengthen the supervision mechanism for the operation and management of pension funds, eliminate illegal use of funds such as misappropriation, and unscrupulous investment behaviors that ignore risks, ensure the safety of funds, and enhance the confidence of insured personnel in maintaining and increasing the value of funds.

\section{CONCLUSION}

The reform of the endowment insurance in colleges and universities is a major decision in the process of comprehensively deepening the reform in China. The reform has made it possible to transfer and connect the basic endowment insurance between enterprises and institutions, effectively promoting the free flow of college teachers and greatly reducing the aging. The financial pressure generated also brought an opportunity for the university to deepen personnel reform. Under the overall situation of reform, the reform of the endowment insurance system in colleges and universities is explored, which is in line with the needs of national policies and an inevitable trend of social development to a certain level.

\section{REFERENCES}

[1] Li Hanlin, Qu Jingdong. Institutional normative behavior---research and thinking about units [J]. Sociological Research, 2002, (5): 1-22.

[2] Yin Liping, Zhang Xiangqian. Research on the Influence and Countermeasure of Pension Reform in Public Universities: Based on the Analysis of Double Track System [J]. Technology and Industry, 2016(7): 143-149.

[3] Zeng Liping, Zhang Li. Analysis on the reform of the endowment insurance system in colleges and universities [J]. Manager, 2016(4): 56.

[4] Chen Zongchun. Analysis on the reform path of pension insurance in colleges and universities under the supervision of pension [J]. Science and Education Literature: The next issue, 2016 (7): 141-142. 